\title{
Third Parties in Home-School Connections: Learning from Conversations with Nondominant Families Crossing Cultures
}

\author{
Elena Lyutykh, \\ Concordia University Chicago \\ Illinois, USA \\ Martha J. Strickland \\ Pennsylvania State University-Harrisburg \\ Pennsylvania, USA \\ Lyn Fasoli \\ Batchelor Institute of Indigenous Tertiary Education \\ Northern Territory, Australia \\ Beatrice Adera \\ West Chester University of Pennsylvania \\ Pennsylvania, USA
}

\begin{abstract}
Guided by a networked model of Ecological Systems Theory, this qualitative study listened to nondominant families who had crossed cultures and sent children to schools in cultural contexts different from those of the parents' upbringing. Researchers looked at the mesosystemic interactions between the microsystems of the family and the microsystems of the school through the eyes of the families in order to capture "third parties" and common patterns of social relations and interactions that families engaged in around school. Families insisted on keeping home and school settings separate and revealed complex social networks that mediated families' thinking about school and motivated alternative conceptions of their involvement in their children's education. Implications are discussed.
\end{abstract}

Millions of families cross cultural terrains globally while seeking a better life for themselves and their children (Settles, 2001). There is a pressing need for research to inform and enhance the achievement of children from nondominant cultures entering school contexts in cultures different from their parents' experience. Some have linked the academic achievement 
challenges of these children to discontinuities between home and school (Tyler, et al., 2008), including language differences and dissonances of cultural beliefs and values (Coll \& Pachter, 2002). To address such dissonances, research is replete with school-directed strategies on how to reach out and involve diverse families in school (Christenson \& Sheridan, 2001). However, it is not clear whether practices focused on connecting dominant families with schools also work for nondominant families - particularly those who are crossing cultures (de Carvalho, 2001; Vazquez-Nuttal, Li, \& Kaplan, 2006).

There has been a relatively strong pipeline of studies on educational issues and achievement of children in schools within a context different from their parents' cultural experiences that seek to enhance cultural understandings and foster respect for diversity in schools (McCarthey, 2000; Trumbull, Rothstein-Fisch, Greenfield, \& Quiroz, 2001; Valdez, 1996). These studies typically conclude with suggested strategies for schools or teachers to employ. However, the designation of such a repertoire of strategies exposes what Gutierrez and Rogoff (2003) have identified as the tendency of researchers to place the student as a "carrier" of culture and assign an "overly static and categorical" list of characteristics to a culture (p.

19).While many of these studies successfully underscore diversity in present-day schools and challenge what is identified as a "color-blind" understanding of home-school relationships, the nondominant families are not represented (Baquedano-López, Alexander, \& Hernandez, 2013, p. 149). Yet, the schools face a daunting challenge to involve parents from nondominant cultures as they seek to create a community out of the unprecedented diversity in their classrooms.

Focusing on how relationships within a local ecology inform the development of new relationships, Neal and Neal (2014) demonstrated that universal behavioral tendencies toward forming relationships make it inherently challenging to simultaneously promote both a respect for diversity and a sense of community in a single setting. To date, research on nondominant families crossing cultures has not been able to effectively explain and address the local ecological relationships that play a valuable role in fostering connections between home and school. As Baquedano-López, Alexander, \& Hernandez (2013) note, studies of home-school partnerships either gloss over important contextual differences by staying within color-blind models of parental involvement, or in the quest for promoting respect for diversity, they underscore ethnic and cultural differences to the point of further alienating the very populations school communities wish to engage.

To combat such approaches, Gutierrez and Rogoff (2003) have suggested exploring the "cultural repertoires" that are enacted within dynamic communities. Therefore this study closely examines the social networks of nondominant families crossing cultures in order to better understand the meanings that school practices have for them, and the interactions through which they derive these meanings.

\section{Perspectives}

\section{Focusing on the Experiences of Families Crossing Cultures}

Despite the unprecedented increase in global migration (Nwosu, Batalova, \& Auclair, 2014) and the understanding that immigrant and indigenous parents strongly value their children's education (Audet, 2008; Kanouté, Vatz Laaroussi, Rachédi, \& Doffouchi, 2008; Fleer, 2004; Suarez-Orozco \& Suarez-Orozco, 2001; Trumbull \& Rothstein-Fisch, 2011), views of nondominant families crossing cultures are rarely heard in the research pursuit and their contexts, and networks are often misunderstood by teachers (Baquedano-López, Alexander, \& Hernandez, 
2013; Crozier \& Davies, 2007; Hughes \& MacNaughton, 2000). Indeed, parents who cross cultures regularly perceive school as a means of social advancement and note access to high quality education as one of the main reasons to cross cultural or national borders (Carréon, Drake, \& Barton, 2005; Mo \& Singh, 2008; Suarez-Orozco, Suarez-Orozco, \& Todorova, 2008).

In the scant research, parents' ideas about their roles in children's education, including their sense of efficacy in helping the children to succeed in schools, have been associated with their decisions on how to be involved and how to interpret school invitations to involvement (Chrispeels \& Rivero, 2001; Shumow \& Lomax, 2002). Hoover-Dempsey and Sandler's model (1997) suggests that parents' life context underpins their decisions about school involvement. The life skill variables of "knowledge, skills, time and energy" are identified as most salient in explaining the decisions parents make about their involvement with schools (Hoover-Dempsey et al., 2005, p. 114).

\section{Differing Views on Involvement}

Different views on the topic of school-home partnerships are held by different people depending on the lens they use. The narrow definition of the home-school relationship, defining it as solely parental involvement from a school's perspective, has been challenged as being deeply rooted in a middle-class perspective of what parent involvement means and looks like (Lawrence-Lightfoot, 2003; López, Scribner, \& Mahitivanichcha, 2001; Valdes, 1996). When parental involvement is defined only as parents focusing on classroom and school needs, parent perspectives become invisible. Such a perspective imposes a moral logic on parents by emphasizing that "being successful as mothers means being attentive to schools and teachers" (Griffith \& Smith, 2005, p. 40).

A review of the studies on family involvement relates limited notions of family and involvement that can constrain the support that school staff provide (Hilgendorf, 2012). Some evidence suggests that implicit and explicit differences in values and practices of parents and school staff, and the attitudes of school personnel and their stereotypes toward nondominant families (particularly indigenous and immigrant families), contribute negatively to family -school relationships (Carreón et al., 2005; Fleer, 2004; García Coll et al., 2002; Moosa, Karabenick, \& Adams, 2001; Mellor \& Corrigan, 2004; Trumbull, Rothstein-Fisch, \& Hernandez, 2003; Wong \& Hughes, 2006).

Further, the perspectives of parents have been found by researchers to inform an understanding of family involvement. This is noted particularly in the research focused on indigenous families. Fleer (2004) investigated Australian indigenous parents' perspectives on education practices they valued, in the home as well as in the school, and foregrounded home practices viewed as necessary for non-indigenous teachers to understand in order to address their children's educational needs. Fleer's (2004) findings problematize current understandings of what family involvement means across cultures and highlight the disparity between home cultures and the mono-cultural perspectives within the dominant Australian education system. Similarly, Mellor and Corrigan (2004) highlighted differences between indigenous family and school expectations and attributed the lack of involvement of indigenous parents in their children's schooling as significantly related to school characteristics. These school characteristics included the degree to which parent participation was valued by schools, the kinds of demands the school made on parents, and the willingness of the school to take into consideration parents' multiple responsibilities beyond the school, as well as the resources available to them. 


\section{Barriers vs. Agency in Parental Involvement}

School-perceived lack of parental involvement among nondominant families crossing cultural contexts has been long conceptualized in terms of the barriers that prevent them from active participation in their children's schools. From this perspective, families from cultures in which parental participation has not been emphasized or has not taken the same form as it does in the host culture may be overwhelmed by teacher demands for them to partner with the school (Sohn \& Wang, 2006). Focusing on the experiences of marginalized, low-SES families, researchers often assume that these families want to be involved at school, but find it difficult or impossible due to a number of objectively existing circumstances construed as barriers. Traditionally the barriers identified include insecure employment, diminished availability to take part in school meetings (García Coll et al., 2002; Kanouté \& Saintfort, 2003), and language and cultural differences between the dominant society and families (Denessen, Bakker, \& Gierveld, 2007; Emerson et al, 2012; Klein, 2008; Li, 2006; Wang, 2008). Further, culture shock is also identified as a barrier as families try to navigate new school systems and changes such as the difference in roles they used to play and those expected in the dominant society (Okagaki \& Sternberg, 1993; Valdés, 1996).

Barriers-centered interpretations reinforce inequalities in building effective home-school partnerships, as they ignore the experiences of many diverse families who have the ability to participate but actively question or resist conventional avenues of parent involvement offered by the schools. Few studies examine agency in the parents' decision not to be involved or interpret lack of involvement as a deliberate and intentional choice of the family. Among those who note such a phenomenon is Li's (2006) study of Chinese parents' involvement in literacy and schooling. Li illustrated the cultural conflicts occurring between Canadian teachers and Asian immigrant parents. The middle- and upper-class Chinese parents in this study actively resisted school practices that did not match their own views on education. Family interventions were intended to counterbalance their children's failure to acquire the literacy skills they considered necessary for academic success.

In another study, Lim (2012) focused on a group of middle-class Korean-American parents and documented tensions that existed within the group as they negotiated a shared understanding of the home-school partnership. Tensions existed between those parents who strove to fit the school's standard and subscribe to the ideal of supporting the school by active volunteering and those who revealed resentment against the derogatory labeling of Asian families as "non-participating," and questioned institutional preference for particular forms of expression in the family-school partnership (p. 99.).

Throughout the research there has been only a cursory glance at the dynamic and complex contexts informing culturally diverse families' connection to their children's schooling (Silva, Campbell, \& Wright, 2012). A more sophisticated understanding of how family context relates to the requirements for varying levels of time, effort, and support from educators is needed (Reschly \& Christenson, 2014). Further, more attention can be paid to the parents' networks and pressures that influence their actions regarding school (Griffith, 2000; Sheldon, 2005).

\section{Alternative Views on School-Home Partnership}

When considering the ecological context, research has found that parents whose linguistic and cultural backgrounds differ from those of the dominant culture employ distinct patterns of involvement that may not fit with forms anticipated by the school. For example, Walsh (2002) found that in some East Asian cultures, school tends to represent an authoritative, separate space 
demarcated from home by a clear boundary, meaning that parents do not see being involved in the school as appropriate. As a result, different avenues of parent involvement that were more accessible for them, such as home-based involvement were employed with the parents from East Asian cultures (Walsh, 2002). Researchers focusing on families who have moved to a new culture from Asia have also found that these families tended to engage in a variety of educational activities outside of school to promote their children's learning but were less involved in volunteering or decision-making at schools (Kim, 2002; Siu, 2001).

Often families from diverse ethnic backgrounds view their role in their children's education as supplementing or even altering their children's educational experiences apart from the school context. For example, immigrant parents who enroll their children in ethnic schools are seen as striving to augment or alter children's educational experiences (Carreira \& Kagan, 2011; Lyutykh, 2011). These families also were found to ask questions and obtain additional information about schooling and education and attend events or meetings that align with family goals, albeit often through organizations and social networks outside the school (Poza, Brooks, \& Valdés, 2014).

Turning attention to indigenous families, a study by Lea, et al. (2012) reported significant differences between the views of Australian indigenous families and school staff on issues associated with parent engagement in their children's schooling. School staff responses focused on lack of parent engagement and the perceived barriers to engagement experienced by indigenous parents (Lea, et al., 2012). These were seen as being primarily structural and environmental, resulting in indigenous parents feeling excluded by the very nature of the school as "a culturally distinctive and uncomfortable place for indigenous people" (p. 274). Indigenous parents, in contrast, did not see their levels of engagement as a problem or the school space as intimidating and, instead, expressed satisfaction with the education provided as well as their degree of involvement in the school. The researchers suggest that these findings reveal some fundamental misunderstandings that each group holds about the other and a rather simplistic nod to political correctness on the part of the school.

These studies highlight the need for further research exploring the views of families who have crossed cultures and placed their children in schools outside the parents' cultural experience. There is a pressing need for more work to be done to explore how these nondominant families crossing cultural contexts approach their involvement in their children's schooling, including their children's views on this involvement.

\section{Conceptual Framework}

Bronfenbrenner's (1992) ecological systems theory (EST) has long informed research related to home-school connections. Traditionally EST identifies individuals as developing within five systems (micro-, meso-, exo-, macro- and chronosystem), visualized as concentric circles nested together and radiating outward from face-to-face social interactions (microsystem) to an individual's interactions with cultural belief systems (macrosystem). The mesosystem signifies a social interaction between participants in different settings that both include the focal individual (Bronfenbrenner, 1992). The home-school connection has been conceptualized as residing in the mesosystem insofar as it enables the relationship between the microsystems of school and of home, both of which the child is a part. Merging all five systems into one coherent context, bound by the outward spatial orientation to social interactions, has been a key implication of EST for the study of home-school connections. 
Recently, researchers have increasingly questioned the assumed nestedness and coherence within social ecological systems (Neal \& Neal, 2013). As noted by Neal and Neal (2013), Bronfenbrenner (1979) defined both the microsystem and the mesosystem in terms of social interactions and called for particular attention to accounting for "the indirect influence of third parties on the interaction between members of a dyad, because a focus on dyadic social interactions alone ignores the wider social context and is thus insufficient to capture the social forces bearing on the focal individual" (proposition E; p.68, as cited by Neal \& Neal, 2013, p. 726). Resources, including information and meanings, that parents gain through their social networks also contribute to their involvement in the education of their children (Sheldon, 2005). In this study the networked model of EST was adopted. This model provides for multiple displays of systems that both overlap and remain discrete while being connected and disconnected through social interactions (Neal \& Neal, 2013).

Accordingly, this study attends to the multiple dimensions and actors within culturecrossing experiences as mediating interactions between the home context of nondominant families crossing cultures and school (i.e., mesosystem). Additionally, an ecological understanding of parental engagement warrants shifting from focusing primarily on what parents do to engage with their children's schools, to also considering how parents understand their engagement and how this engagement relates more broadly to parents' experiences and actions both inside and out of the school community (Barton, et al., 2004).

\section{Purpose and Research Questions}

This study sought the views on schooling of nondominant families who are crossing cultures and placing their children in schools that are outside the parents' cultural experiences, with the aim to proffer a wider utility of the present discourse around family engagement than has previously been garnered. The mesosystemic interactions between the microsystem of the family and the microsystem of the school through the eyes of the families was the focus, with the goal to identify common patterns of social relations, interactions, and meaning that families engaged in about school across their diverse experiences. To accomplish this purpose the following questions guided the study:

1. How and with whom do family members interact in making sense of their children's schooling?

2. How do families understand their roles in their children's schooling experiences as a result of their interactions?

3. How do family conversations illuminate efforts to involve these families in school?

\section{Methodology}

\section{Design}

In this qualitative study, a constructivist grounded theory approach (Glaser \& Strauss, 1967; Charmaz, 2000; 2014) was employed to explore, understand, and theorize how nondominant families who have crossed cultures understood and enacted their relationship with schools in a cultural context different from that of the parents' upbringing. Constructivist grounded theory is particularly appropriate for this study because it adopts an inductive, comparative, emergent, and open-ended approach to data analysis, focusing on actions and 
processes (Glaser \& Strauss, 1967). Informed by the ecological understandings, the focus of this study was on the social interactions within the child's life to locate key actors that participated in the home-school networks. Further, when seeking to understand the content and organization of the school-family mesosystem, the researchers "allowed ecological systems to emerge from the data rather than to be defined in advance based on a priori assumptions" (Neal \& Neal, 2013, p.735). An ecological framework and constructivist orientation dictated sensitivity to the participants' reality. Conversational interviews with families were chosen as a data collection method because such conversations powerfully expose participants' understandings of their experiences (Ochs \& Taylor, 1992; Pontecorvo, 2007).

Aligned with recent research calling for "divergent reasoning," (Neal \& Neal, 2014, p. 10), the present study's focus was on a diverse group of families as opposed to a homogeneous sampling. In contrast to limiting the research group to a particular set of demographic characteristics, this group of participants was defined by having lived through the experience of crossing cultures. Because the experience of moving to an unfamiliar cultural context and entering as nondominant is becoming so common in today's globalized world, this sample serves as a context for building an understanding of home-school ecology that both acknowledges diversity and promotes empathy and a sense of community - called for by recent researchers (Neal \& Neal, 2014).

Participants were not randomly selected or predetermined during the planning stages of the project. Rather, the selection criteria required that each family include school-aged children and had moved into their local school districts from a distinctively different cultural region. To find suitable research participants, each researcher recruited families that fit these criteria through their professional and personal networks. Then, employing a snowball sampling technique (Biernacki \& Waldorf, 1981), these families were asked to identify additional families who, like themselves, had crossed cultures and had children of preschool, primary, or secondary school age attending schools that were culturally different from the schools attended by adult family members. To ensure that families did not feel pressured to participate through their relationship with researchers, their voluntary informed consent was explained thoroughly before the research commenced, and they were reminded throughout the research that they were free to withdraw from the research at any time for any reason.

The inclusion of Australian indigenous families in this data set does not mean that their circumstances were believed to be the same as immigrant populations, as they clearly are not, given the history of colonization and its effects. However, those Australian indigenous families involved in this study do share with immigrants the experience of crossing cultural borders and of sending their children to schools that are distinctly different from the schools that adult family members attended. The participation of indigenous families in the study provided an opportunity to disrupt a pervasive deficit discourse that surrounds indigenous education in Australia and in the Northern Territory (Osborne, 2015) by highlighting common issues associated with homeschool relationships.

The design of the study also capitalized on the diverse cultural backgrounds and crosscultural experiences of the researchers. All four researchers - 2 immigrants to the U.S. and 2 American-born - had crossed cultures and lived outside of the cultural context of their upbringing. Therefore the researchers and the participants shared the experience of being in an alien cultural context. Having such a shared experience enhanced the descriptive and interpretive validity of this study (Maxwell, 1992) insofar as it uniquely positioned the researchers to "noticing" (Friese, 2011), that is finding patterns in the families' understandings of the home- 
school connections, which transcended each individual culture. In addition, two of the researchers speak the native languages of the participants (Kenyan and Russian). The assistance of an interpreter/cultural insider was solicited when interviewing indigenous families.

\section{Procedure}

The institutional IRB approval was obtained, and through the researchers' personal networks, families were recruited for interviews in the U.S. and Australia. The interviews were conducted over the period of 15 months in 2012-2013. Researchers contacted each family and arranged to meet at the place and time that was convenient for the family. The goal was to have the entire family, parents and children, present and talk about their experiences with school. At the meeting, the parents were first given information about the study and the consent process; they were also asked for permission to record the interview. Once they were assured of confidentiality, they signed a consent form while the children assented. The data collection proceeded with parents responding to a questionnaire and family conversation afterwards.

Two instruments were used for data collection. The first was a socio-demographic questionnaire that solicited information on the participants to garner family constellation information and migration history. The information requested included the following: place of origin, number of years in the present location, number of children and their ages, language and education background, and employment status. The second instrument was an intensive qualitative family conversational interview lasting 60-90 minutes. During the interview, the families were asked to describe broadly their experiences with schools and thoughts around language, peers, and transition. Then they were asked specifically about their interactions with teachers, the school team, the school environment, and the community. This combination of focused attention and open-ended inquiry through intensive interviewing aligns with the grounded theory approach, as it "enabled researchers to take successively more analytic control over data collection and emerging theoretical ideas" (Charmaz, 2014, p.85). Each conversation was transcribed verbatim (Iannaccone \& Marsico, 2013; Pontecorvo, Fasulo, \& Sterponi, 2001).

\section{Participants}

In all, 15 families were interviewed. The families resided in four different states in the U.S. and in Australia. All families had at least one child attending local schools. Among the 15 interviewed families there were 30 adults and 34 school-aged children, between 4-16 years old. Eleven families moved to the U.S. from Kenya, Pakistan, Russia, Lithuania, Ukraine, India, and four families in Australia transitioned from a remote Aboriginal community to an urban school in the Northern Territory (NT). Table 1 presents the participants' demographic backgrounds.

Table 1. Summary of Participant Descriptions

\begin{tabular}{|l|l|l|l|l|l|l|l|l|}
\hline & \multicolumn{3}{|c|}{ Family } & \multicolumn{2}{c|}{ Parents } & \multicolumn{3}{c|}{ Children } \\
\hline $\begin{array}{l}\text { Present } \\
\text { Location }\end{array}$ & $\begin{array}{l}\text { Years in } \\
\text { Location }\end{array}$ & $\begin{array}{l}\text { Home } \\
\text { Language }\end{array}$ & $\begin{array}{l}\text { Culture of } \\
\text { Origin }\end{array}$ & $\begin{array}{l}\text { Highest } \\
\text { Education }\end{array}$ & Gender & Age & Born \\
\hline US: PA & 2 & Swahili & Kenya & College & F & 8 & Kenya \\
Kenya
\end{tabular}


Elena Lyutykh et al.

\begin{tabular}{|c|c|c|c|c|c|c|c|}
\hline US: PA & 2 & Luo & Kenya & $\begin{array}{l}\text { High } \\
\text { school }\end{array}$ & $\begin{array}{l}\mathrm{F} \\
\mathrm{M} \\
\mathrm{F}\end{array}$ & $\begin{array}{l}16 \\
12 \\
5\end{array}$ & $\begin{array}{l}\text { Kenya } \\
\text { Kenya } \\
\text { Kenya }\end{array}$ \\
\hline US: IL & 1 & Russian & Ukraine & College & $\mathrm{F}$ & 10 & Spain \\
\hline US: IL & 9 & Russian & Russia & College & $\begin{array}{l}\mathrm{M} \\
\mathrm{M}\end{array}$ & $\begin{array}{l}12 \\
3\end{array}$ & $\begin{array}{l}\text { Russia } \\
\text { US }\end{array}$ \\
\hline US: IL & 13 & Russian & Russia & College & $\begin{array}{l}\mathrm{M} \\
\mathrm{F}\end{array}$ & $\begin{array}{l}16 \\
12\end{array}$ & $\begin{array}{l}\text { Russia } \\
\text { US }\end{array}$ \\
\hline US: IL & 10 & Lithuanian & Lithuania & $\begin{array}{l}\text { High } \\
\text { school }\end{array}$ & $\begin{array}{l}\mathrm{M} \\
\mathrm{M}\end{array}$ & $\begin{array}{l}8 \\
6\end{array}$ & $\begin{array}{l}\text { US } \\
\text { US }\end{array}$ \\
\hline US: PA & 8 & Urdu & Pakistan & College & $\begin{array}{l}\mathrm{M} \\
\mathrm{F} \\
\mathrm{M}\end{array}$ & $\begin{array}{l}16 \\
14 \\
4\end{array}$ & $\begin{array}{l}\text { US } \\
\text { US } \\
\text { US }\end{array}$ \\
\hline US: PA & 3 & Urdu & Pakistan & PostGrad & $\mathrm{F}$ & 14 & Pakistan \\
\hline US: PA & 6 & Urdu & Pakistan & PostGrad & $\begin{array}{l}\mathrm{M} \\
\mathrm{F}\end{array}$ & $\begin{array}{l}9 \\
5\end{array}$ & $\begin{array}{l}\text { USA } \\
\text { USA }\end{array}$ \\
\hline US: WI & 2 & Gujarati & India & College & $\begin{array}{l}\mathrm{M} \\
\mathrm{F}\end{array}$ & $\begin{array}{l}15 \\
12 \\
\end{array}$ & $\begin{array}{l}\text { India } \\
\text { India }\end{array}$ \\
\hline Australia: NT & 5 & $\begin{array}{l}\text { Yolngu } \\
\text { Matha }\end{array}$ & Indigenous & $\begin{array}{l}\text { High } \\
\text { school }\end{array}$ & $\begin{array}{l}\mathrm{F} \\
\mathrm{F} \\
\mathrm{F}\end{array}$ & $\begin{array}{l}16 \\
12 \\
8\end{array}$ & $\begin{array}{l}\text { Australia } \\
\text { Australia } \\
\text { Australia }\end{array}$ \\
\hline Australia: NT & 7 & $\begin{array}{l}\text { Yolngu } \\
\text { Matha }\end{array}$ & Indigenous & College & $\begin{array}{l}\mathrm{M} \\
\mathrm{F} \\
\mathrm{M} \\
\mathrm{M} \\
\mathrm{M} \\
\mathrm{M} \\
\mathrm{M}\end{array}$ & $\begin{array}{l}13 \\
12 \\
11 \\
9 \\
7 \\
3 \\
1\end{array}$ & $\begin{array}{l}\text { Australia } \\
\text { Australia } \\
\text { Australia } \\
\text { Australia } \\
\text { Australia } \\
\text { Australia } \\
\text { Australia }\end{array}$ \\
\hline Australia: NT & 5 & $\begin{array}{l}\text { Yolngu } \\
\text { Matha }\end{array}$ & Indigenous & $\begin{array}{l}\text { High } \\
\text { school }\end{array}$ & $\mathrm{M}$ & 12 & Australia \\
\hline Australia: NT & 9 & $\begin{array}{l}\text { Yolngu } \\
\text { Matha }\end{array}$ & Indigenous & $\begin{array}{l}\text { High } \\
\text { school }\end{array}$ & $\mathrm{F}$ & 5 & Australia \\
\hline
\end{tabular}

\section{Data Analysis}

A grounded theory approach was employed to analyze the narrative data from interviews using Dedoose software (2014, Version 5.0.11). Grounded theory coding is the process of identifying what data are about. In the first pass of line-by-line reading of family narratives, the researchers examined the stories being told, trying to understand the actors and interlocutors that the families engaged with throughout their experiences. The actors with whom families interacted about school were coded, and open codes were constructed for what the participating families talked about or experienced during those interactions. Noting with whom the participants made sense of their school-related experiences, the researchers began to make analytic sense of the participants' meanings and actions through constant comparison: a method comparing new data to previous data while analyzing in order to develop a grounded theory (Strauss \& Corbin, 1990). The initial what codes opened paths for further analysis focusing the coding by synthesizing and analyzing larger segments of data that described participants' beliefs about and experiences with 
school (Charmaz, 2014). Finally, axial coding brought the data back together by linking the participants' discourse on what they believed about school with whom they were interacting about it. Guided by the research questions, individual what coding units, corresponding to particular whom, were identified within the home-school mesosystem and subsequently mapped out. Common patterns in the proximity of the what-whom processes emerged within the home/school mesosystem. Through constant-comparison analysis, interpretations, and syntheses of the emergent themes, a conceptual framework emerged indicating what Neal and Neal (2013) identify as third parties.

\section{Findings}

In this study, the families referred to four groups of people as their sources of information related to understanding school. These third parties were found to inform the families' homeschool interactions, deepening understanding of their complex mesosystemic interactions with their children's schools (Neal \& Neal, 2013). The families expressed their interactions with each third party in such a way as to reveal distance to each third party group, enabling ecological mapping of their interactions (see Figure 1). Further, across all conversations these third party interactions revealed the perceived role of the home in relation to the school and the perceived role of the school in relation to the home.

\section{Mapping Third Parties in the Home-School Mesosystem}

The participating families that crossed cultures and placed their children in the local

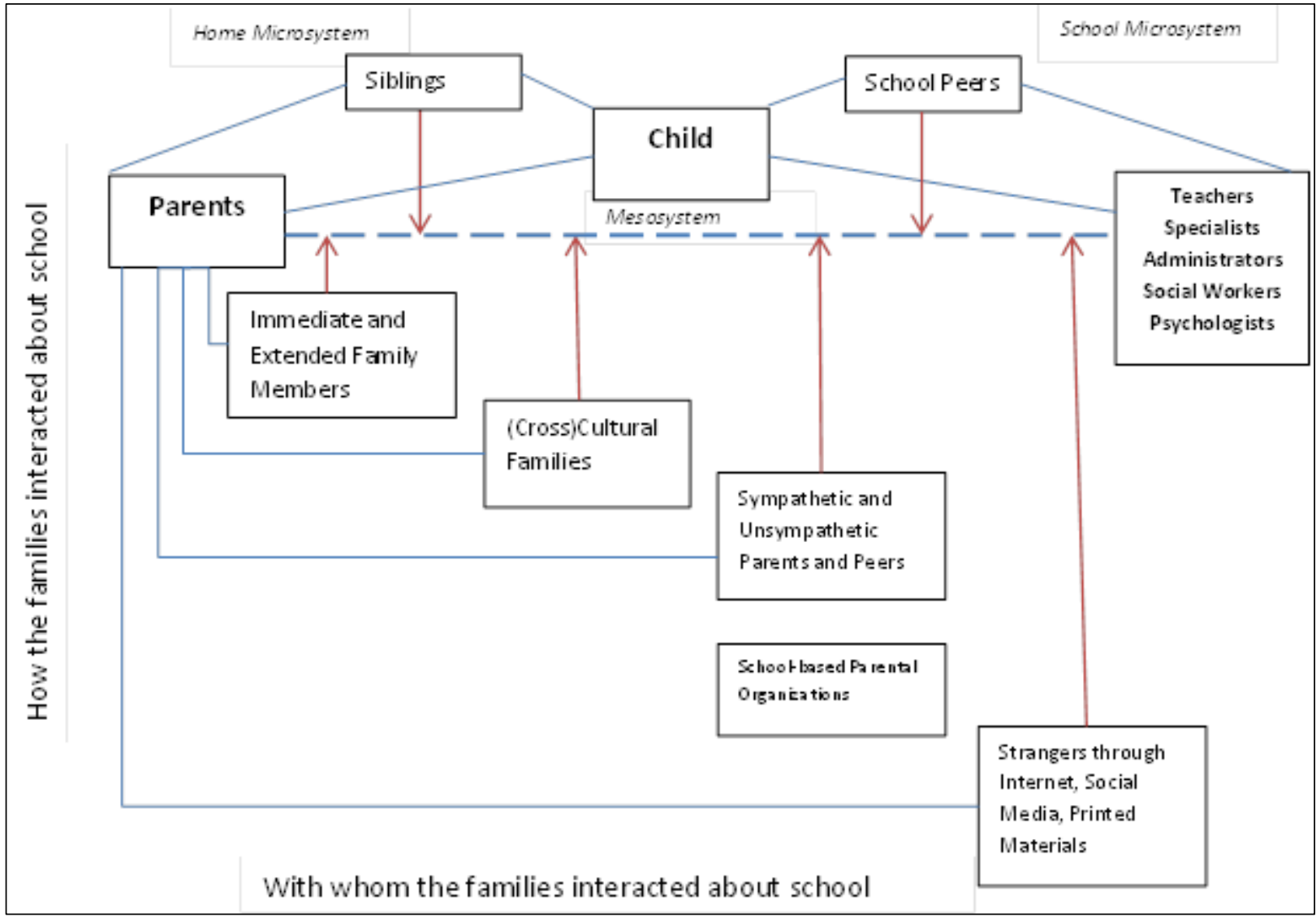

Figure 1. Third parties in the Home-School Mesosystem 
school reported having conversations and interactions about the schooling of their children with multiple third parties. Mapping these parties and associated discourses revealed a complex system of networks that the families enacted and consulted with as they made sense of their everyday school-related lives. Figure 1 illustrates the networks that emerged from the data, in the context of a traditional depiction of the EST mesosystem as a link between the home and the school microsystems and the distance noted between the parents and the third party.

The horizontal dimension depicts the types of third parties that emerged from the data, including: immediate and extended family members, other people of the same background as well as those who crossed cultures ("cross-cultural families"), parents identified as sympathetic or unsympathetic towards them, strangers and experts engaged via use of technology, and school experts, teachers, and administrators. The vertical dimension places these third parties in relative proximity to the families by the degree of presence of these actors in the narratives that were analyzed. All families mentioned conversations with family members and cross-cultural families, securing those parties' closest position on the map. However, prevalence of other third parties varied across families: Families from Russia and India mentioned all of the networks; while families from the Ukraine, Pakistan, and Kenya mentioned some of them; and the Australian indigenous families only spoke of interacting with their families and cross-cultural families.

In the subsequent sections these family networks are explained and used to describe emerging third party mediated narratives that the participating families engaged about schooling of their children. The subsequent findings elaborate on the families' understandings of (1) the role of home in relation to school in the local context and (2) the role of school in their children's' lives. These themes cross each third party shaping a mesosystemic relationship that is characterized by interaction that both promotes connection and disconnection between home and school, depicted therefore by a dashed rather than a solid line on Figure 1.

\section{Third Party: Immediate and Extended Family Members}

Perhaps not surprisingly, all families emphasized the strong impact that immediate and extended family members played in their views and decision-making about the education of their children. In some cases, the extended family was on location and in others the extended family was in the parents' passport country. Regardless of these circumstances, interactions with immediate and extended family about educational choices and daily matters were in the closest proximity to the interviewed families.

Indeed the most intimate conversations about school issues were kept within family circles. A Ukrainian mother, who had migrated from the Ukraine via Spain before finally ending up in the U.S., shared that her daughter cried at home because she did not speak English at first. This situation was kept in the family because they "knew how to handle this:"

She was crying a lot because she did not understand English, so we would sit and translate the textbooks. It was a good practice for me as well. But then she got into the swing of things quickly. But all was as we expected. Since we immigrated once already, we knew what to expect; it was not a shock for us. We were prepared to handle this. (Ukrainian, 10432)

The daughter also talked to her about not being accepted by the "White American girls," but would not bring this concern to the teacher. 
Of course this upsets her a lot, but I tell her not to take it too seriously. When you go to middle school, there will be new kids and new opportunities, so I tell her not to think too much about this. It will all fall in place eventually (Ukrainian, 15432)

An Aboriginal mother shared with other family members her disappointment in the new school her children were attending because of a lack of attention to language issues. She was anxious about leaving her children in a school where they could not communicate with teachers because of language differences and concerned that the school did not have a strategy for supporting such children.

These kids don't have English. They will find it hard - to talk back to the teachers and to the people around the school, it's really hard. Do they get that support? They didn't get it. (Aboriginal Family, 1183)

Role of home. Within these conversations, parents described their role as the protectors of their language and culture and as acting as a bridge between their children and their extended family.

Well, we do speak Russian at home, of course she has an accent, but she has a Spanish accent. Her native language is Spanish. I was trying to preserve her Russian in Spain too. I did not let her speak Spanish at home, so I am hoping that we will maintain the Russian language here as well. (Ukrainian, 18677)

They also talked about their role in bridging home culture to heritage culture and to wider networks as illustrated in the following parent's comment.

Of course I tell Valeria all the time that she needs to study, to learn, to try hard. She needs to merge into the society where she lives. She needs to adapt to this culture and society, not the other way around. I think if you come here you must find a way to fit in. (Ukrainian, 18862)

An Aboriginal grandmother provides another example of the protective and bridging role played by families.

When she [the granddaughter] came to the town I take her to the school...She was a nothing. She never been taught. . . she was crying, crying, crying. I took (her) every day to the school and I was sitting there looking after her...She's gonna suffer if I'm not there. It makes me sad too if she's suffering... No one was there. No Yolngu there. No one to speak her language. (Aboriginal 3, 708)

Role of school. Within their interactions with immediate and extended family members, the parents talked about reasons for their move across cultures, describing the role of school less as a place than as an entrée to a desired future for their children. For the immigrant families, sending children to an American school by itself constituted a source of pride that they shared with their relatives close and far. 
The parents described school as giving their children access to powerful language and to ways of acting and thinking necessary for a successful future. A Ukrainian mother spoke of her confidence in the capacity of American schooling to provide her children with a bright future.

Here the kids are told that if they study hard and work they will have brilliant future and this is really the case. It is true. There, it is all about who you know and corruption.

(Ukrainian Mother, 20911)

A Pakistani father endorsed the American system of education for new opportunities he saw it offering his children.

....and that's what brought me to the U.S. in the first place, the creativity aspect of learning. The way that you are encouraged to have your own independent thinking, that is, I think, the biggest strength in the education system here...And I see it also in my kids, the same thing. (Pakistani2, 6890)

An Aboriginal mother, while seeing her children's access to English through the school as a "good thing," revealed ambivalence about its overall impact.

The younger kids are losing language. But they learning more English and that good thing. But losing culture. (Aboriginal Family 4, 4430)

\section{Third Party: (Cross) Cultural Families}

Second in the proximity to the interviewed families were other families of similar cultural backgrounds, as well as more generally, other persons who had crossed cultures as nondominant families and entered the local school in a cultural context different from the parents' experiences. The role of home and school was also related within these networked relationship narratives.

Role of home. When referring to conversations with others who crossed cultures, families described a tricky dance of raising children who could deal with both of the cultural worlds they inhabited. These families occupied a space in between their home cultures and the culture of their host culture, which shaped their interactions and practices in distinct ways. The adult family members were well aware of the fact that their children were not becoming Russian, Pakistani, Kenyan, or Yolngu in the same sense as children who actually grow up in those cultures. Their challenge, as they described it, was to carve out their unique identities within the dominant context in which they were located.

This [school] would be a futile effort [that] if I want to make them Pakistani kids. They are American kids. They have to live here. My time is a lot shorter than theirs on this earth. So they have to live. And they are not going to go back to Pakistan. I always have a desire to go back and serve, and generally I could. As any immigrant, we always, $99 \%$ of us at least have a desire. Whether we do or not, that's a different thing. But they're American kids. So we find a broader sphere where they can fit and don't feel left out or alone. So that's where there religion comes in. You can make them better Muslim, which means a better person. And culturally, you modify. You modify. You have ground rules. You stick with them. And then you modify. That's a day-to-day decision that you have to make. (Pakistani1, 46534) 
This experience was shared amongst those who crossed cultures regardless of their heritage. The essence of this experience is quickly understood within the network of cross-cultural insiders.

Role of school. As these families talked with third-party families crossing cultures, they particularly noted their shared perception of low rigor in a variety of content areas in the schools their children attended. This was mentioned frequently as illustrated by the following comments.

I brought with me books from India, and I make them study those things too. For math and stuff. Because I don't want them to be, you know, behind. We want to make sure that he [son] is at least going forward with what he knows that he is coming up with something new. So, now he is in the 9th grade and the books for 9th grade in India are the same as in 12th grade here. (Indian, 8936)

I teach her something in math, but then she goes to school and tells me the teacher told me to use building blocks. If you ask me, I'm training her to do math mentally, but here they are doing it using blocks and all that. I think they are moving too slow in terms of building blocks. When should she stop building blocks and catch up to where she was? (Kenyan 1, 6896)

There's no learning language at the school either. They don't learn to read and write in Yolngu Matha. (Aboriginal 4, 4958)

It was evident that this view of education received by children as incomplete was not only shared across all families in the sample, but was something that they actively discussed in interactions with networks beyond the school, with other parents of similar backgrounds.

\section{Third Party: 'Sympathetic' and 'Unsympathetic' Parents and Peers}

Throughout the conversations there emerged descriptions of interactions with parents and peers located both inside and outside of the school context. These were described as either sympathetic to their situation as newcomers to the cultural context of school or unsympathetic.

Describing their interactions with the sympathetic and unsympathetic parents and peers, the children and parents talked about social interactions with their peers in two ways. On the one hand, as the school challenged them to speak a new language and learn to get along with unexpected protocols and people, the families talked about trying to solicit and often received help from those they viewed to be 'sympathetic' people. For example, frequently across all families, the children talked about having to learn how to navigate unfamiliar school requirements and mentioned their peers as sources for acquiring knowledge or as models for successfully meeting challenges, and these peers were typically children from diverse backgrounds. For example, one child from the Ukraine stated, "I had a friend who was Mexican. She helped me a lot, because we could speak Spanish to each other" (Ukrainian, 2682).

When asked what made it easy for her when she first started in her new school, an Aboriginal child talked about her 'mixed race' friends being her 'defenders' as noted in the following quotation: "We have mixed race friends.... Now we have, like, a support group, a defender, they have our back, telling us not to do that (fighting)." (Aboriginal 1, 6907). 
On the other hand, unanimously, the families reported being stunned and unprepared to face difficulties in connecting with 'unsympathetic' others on a more personal level. These experiences ranged from feeling marginalized and invisible to experiencing active bullying by representatives of the dominant groups. Across the families, both the parents and the children talked about native-born peers as being surprisingly reserved, unfriendly, and not welcoming. As Ukrainian and Kenyan mothers put it:

Well, it looks like Americans do not care about anything. They sort of look at you like "it's ok," but they do not really care. No emotion, they do not keep the conversation. Very reserved. They all smile and seem nice, and they hold their faces well, but when it comes to being friends, they let you know quickly that you are not like them and they do not accept you. (Ukrainian, 2)

Here in America the people around here, they are so individualistic. You try to interact with them and they just push you. That's the same case that happens to this child when she goes in school. The first day when she went to school no one was talking to her and she came home and said "Mommy, I don't have a friend, I don't have a friend." You even wake up and go to the teacher and say, "You be her friend now. Stay with this kid, teach her." (Kenyan 1, 15300)

In other circumstances the participants described being bullied by peers because of their cultural differences, but, nevertheless, talked about bullying as expected. Whereas bullying was central to the children's network, these experiences were kept outside the parents' view. In some cases, the first time parents learned about these experiences was during the family research conversations.

And sometimes I'll bring Pakistani food to school. And it will be this spicy aroma and everyone would be, “ew, get away from me.” It was annoying but—ah. But I always try to use being Pakistani, but it usually never works out because they're like, when Afghanistan and Syria and everything was what's going on, they sometimes would make fun of me. I remember one time this person just said, "oh, you're from Pakistan, do you know Osama?" (Pakistani1, 33264)

They know how to bully without that physical touch, without that facial expression that you can actually attach to. You know when you are walking and all of a sudden somebody pretends and they all move away from you and then you are left isolated. Or like on the bus. Assume there is one seat that is vacant next to somebody and you go sit there and the other person stands up and walks away. Or you find when people are seated, I think the chairs are in twos next to the windows, and the one seat their seats next to the aisle in the middle, and leaves the seat empty, the one next to the window and puts their bag there when they see you coming. So it is a very silent way of intimidating you and telling you, not here... You come home, and when you get home, you just wishing tomorrow doesn't come. (Kenyan, 28915)

Role of home. With the third party parents and peers, families shared awareness that many people around them were ignorant about their heritage cultures, religions, and traditions. 
For some families, this lack of understanding included the need to educate them. A 16-year-old son of the Pakistani family expressed it this way:

You're probably going to be the only Muslim in the entire grade, let alone that class. And one thing I would just say is, just make sure that you're not quiet. They need to learn. You're in a 90\% white school. The only experience they're going to have with a diversea different person, other than maybe college - is you. You're the only person that they're going to interact with that's not white. And you need to make sure that before they go and call-just completely insult somebody, you need-I know it's a weird thing to say but it's kind of our responsibility to educate them (Pakistani1, 55705).

In marching band, at the beginning, where we learned what we had to do, like our moves, we go to band camp. So it was four days at band camp. And I was fasting. It was Ramadan during those four days. And it's really hard to go without water just for that, but I had to go before that and after that, too. So people were asking me, how can you do this? And they got really curious then. And I remember I was absent the first two hours of band camp the last day because it was the Eid that day. And it was really...everybody was asking. They were really curious. (Pakistani2, 42146)

Role of school. Many of the parents included school-based parental organizations as the school-driven source of information for them as they navigated the foreign school context. However, the parents described how they quickly learned that they did not really fit with schoolbased parental organizations and felt irrelevant in organizing school events and activities. In fact, it was sometimes the very structures that existed to bridge homes and schools that further alienated these families from being part of the school communities. This is illustrated in the following quotations:

Go to the PTA and you'd be surprised how many volunteers are willing to help. But when a school doesn't identify the potential in some of the PTA members, then they just remain like meeting only, like attendance only. (Kenyan 2, 17468)

One thing is that there are always American parents in charge there [school events and PTA meetings] and the thing is that we feel that they do not really interact with us. They don't want us to participate; they kind-of have their own groups and want to be left alone. So there is no point for us to get there. They don't really involve us in any way, nor do they want us there. They don't let us inside. (Indian, 13892)

We go to school, whenever there is this thing that they call and the parents and, you know, we are going to school to talk to one another, and you leave that school going back home having spoken to the teacher and perhaps only two more parents who ask "where are you from?" and they say, "oh, that's good your daughter is catching up." Yeah, those are two questions they never miss: "where are you from and for how long have you been here?" and then, "your child is doing good for those three years." (Kenyan1, 17471) 


\section{Direct Interactions with Schools: Teachers, Administrators, Specialists}

Further away from the families are their interactions with the school. Throughout their conversations, the families framed their interactions with teachers, administrators, and specialists as challenging. Their placement and descriptions of these interactions situated them at a distance. For some parents it appeared that schools did not listen, ask any questions, or respond to their confusion or criticism. So the parents quickly learned that they should keep their opinions to themselves, even if they did not embrace school practices, as illustrated in this description by a Kenyan parent:

I remember that we were both involved and we taught her so much especially in school and teaching. And me with my background in teaching, my experience as a teacher is especially...I was so much into it and my expectation was that even when we came over I would have a lot of input. We would both participate in her development. But it has not been. ... I will not interfere with what you [the teacher] are doing because I will confuse this kid. (Kenyan, 6177)

An Aboriginal family expressed frustration when the school did not appear to understand how to communicate with them. In the remote community school where they lived before moving into town, non-Aboriginal teachers always worked alongside Aboriginal assistant teachers who, being from the same family and language background as the children, knew how to engage with Aboriginal families. "The connection and the relationship is there so they can talk about family that way." (Aboriginal Family 4, 2730) In the new school, non-Aboriginal teachers did not appear to know how to reach Aboriginal parents.

So the parent is waiting for the teacher to initiate the conversation. And maybe the teacher thinks she's /he's made efforts to involve parents through newsletters, open days, assembly, parent-teacher night. (Aboriginal Family 4, 2730)

Role of home. Talking about the school, the families regularly described a shared experience of schools calling home whenever anything went wrong in the classroom. They noted that the schools were quick to contact homes. The families interpreted these contacts as requiring them to deal with the problems identified in school. Depending on the severity of the issues, the families experienced and perceived these interactions differently. Some, like this Ukrainian mother, welcomed the teachers' feedback and seemed relieved to be asked for parental assistance.

I am very happy with teachers at school; they call us if there is any problem. They tell us what we need to work on, which helps a lot. I have no complaints about school, very pleased with it. Teachers are great. (Ukrainian, 4518)

Others expressed frustration over school's inability to deal effectively with behavioral problems as they arise in the classroom and with what they perceived to be an over-reliance on involving parents in school matters, as illustrated in this Lithuanian parent's narrative.

He is an 8-year-old boy, you see he likes to move a lot and he likes to play. I guess they expect him to sit still and listen, but he does not want to. So they complain. They call and 
call and they ask us to come to school, which we do. But it's like "what exactly do you want me to do about this?" This is very different from when we were growing up. I mean we had all kinds of kids, some were better pupils than others, but teachers dealt with them somehow. Like my mom would only come for a teacher-parent conference twice a year; that was it. Of course, there were kids whose parents would come to school more often, but that was something extraordinary. Like you had to be in fight or like really disrespectful to the teacher or something. He is not a bad boy, he is not aggressive or anything. He just is not interested in school stuff and he does not follow their rules well. He just does whatever interests him. I understand it must be difficult for them, but calling me is not gonna solve this. What should I do? I tell him to sit and listen in school, but he still does not (Lithuanian, 3562).

Role of school. Direct interactions with school personnel were initiated by the schools and typically happened over issues or problems that a child experienced. So from the perspective of these families, there was no reason to be involved at school or to be in any direct interaction with the school if all is well and there are no complaints. When "things go well," the families noted, social interactions were limited to sending their children to school, attending teacherparent conferences, or participating in special 'cultural days'. Notably, such descriptions were not stated as needing to change but as an acceptable situation.

I've met with their teachers. I've made an effort to meet with the teachers . . . . I think that once per 6 months, but think I've made an effort to be there, to at least talk to them, to see what's going on. And I didn't ask them much question. They just told me whatever. They're basically - I think they're telling everybody that your kid is very good, your kid is very good, your kid is very good. And so nobody asks them questions, and everybody's happy. (Pakistani2, 24612)

I never had to visit the school. No need. They have a good system here. Good style of educating people, so no complaints at all. (Indian, 12073)

Further, teachers were often seen as "kind" and willing to help, but also naïve in their requests for simplistic cultural practices such as home foods and in their lack of interest in cultural thoughts or approaches to life or school. One Kenyan parent expressed this sentiment clearly.

I noticed he was struggling a little bit and I made sure he is going to school and the teachers are assisting him with his homework. So I feel the teachers are putting in something extra. Giving that teacher that is free, so as long as the kid is willing to give it. So, to me, that is thumbs up. So, if they are able to identify if a child is struggling, they are there to help. (Kenyan, 23769)

When asked what made it easy for her when she first started in her new school, an Aboriginal child talked about teachers helping by pairing her with another child and asking her if she needed help. However, she also lamented that the teachers did not seem to understand how to work with children from her culture. 
The teachers have a different expectation. The way Yolngu kids listen to the teacher's voice is different to what the Balanda (non-Yolngu) kids listen. They think the teacher is telling them off all the time but it's just the normal way that Balanda teachers talk to kids. In (her old community school) the teachers don't talk like that. Teachers in town didn't know how to talk to Yolngu kids. It's a different way of talking. Yolgnu kids don't have any idea. The teachers don't understand. It makes problems for both. (Aboriginal 4, 6354)

\section{Third Party: Strangers through Internet, Social Media, and Printed Materials}

Throughout the conversations the participating families also mentioned a network that consisted of strangers. Their interaction with the Internet, social media, and printed materials to assist them in understanding the local schools were particularly noted by the families from Pakistan and India. When trying to figure out how schools function, how to evaluate their quality, and what to expect, parents often relied on published sources.

Role of home. Those parents who mentioned this third party of strangers described their pursuit of information as an expected role they had to play as parents.

Well, it is easy, you can Google stuff and learn. Also, you just compare professionals and their work for those who graduated from an American university and from an Indian, and you find that American is much higher than other people from the rest of the world. So American degrees have more value than degrees of other countries. (Indian, 9983)

Role of school. Although rarely mentioned within the conversations, some parents also talked about the information they received from the school via the Internet and printed materials, believing it was the school's responsibility to provide such information.

If, all is well, then everything is on the Internet. They [the school] pass it to us and we just read it. They are good at information. They send information home all the time and we just read it. Hand-outs, print-outs, etc. So we know what is going on . . . What is great about this is that everything is clear, everything is in front of us. So it's not like we don't know what the kids are doing. We know. We keep track of everything. (Indian, 12619)

\section{Discussion}

Building on Bronfenbrenner's ecological systems model, Neal and Neal (2014) suggest that people's mesosystemic networks intersect, exposing third-party interactions as complex, not neatly nested. In this study the views of home and school were expressed by nondominant families who had crossed cultures and placed their children in local schools in a cultural context unfamiliar to their experience. Within this unique family conversational context, their perceptions of the role of school and home revealed the complexity of the ecological networks in three key ways that illuminate efforts to involve nondominant families crossing cultures with the local school.

First, the findings reveal that nondominant families crossing cultures are complex, and their interests and needs are not uniform and cannot be prescribed. While some may resent a requirement that their children engage in supplemental English language learning classes, others may resent that such support is not provided. For example, for the Aboriginal families, both the 
parents and the children were aware of their need for English language support but also wanted the school to acknowledge that they spoke a language other than English. In contrast, the Kenyan family regarded the insistence of the school in providing their children with ESL support as insulting, given that the children had never spoken any language but English. Such complexity suggests that more nuanced understandings are needed of the ways schools can respond to such diverse family contexts that require different levels of time, effort, and support (Reschley \& Christenson, 2014). In order for this to occur, new mechanisms of information exchange between schools and families are needed to provide for more mutual understanding of the issues at stake.

Second, this study draws attention to the valued resources that parents gain through their third party social networks. As the parents noted, they did not expect a continuous resourcing of their home educational pursuits by the school or expect to be held responsible for providing cultural resources to the school and teachers. Their primary concern was that the school equip their children for success in school and thus in their future life in the dominant society. For example, while the indigenous families wanted their children to learn through participation in cultural activities such as funerals, organized by the family, they did not expect the schools to take responsibility for these kinds of cultural activities. Instead, the families in this study emphasized their expectation that schools should enable their children to succeed in the host society/country while also recognizing and supporting the families to provide a space, usually at home, for the expression and maintenance of cultural behaviors.

Third, although limited by the small number of families and cultures represented in this study, the findings suggest a need to refocus the pursuit of connecting culturally diverse homes and schools to include third-party social networks. For these families, their children's schools remained largely unaware of the third-party networks that they were using, closer than the school, to deal with a range of school-related issues and pressures (Griffith, 2000; Sheldon, 2005). This raises the question of how schools can recognize the existence of third-party networks in communication approaches between families who are moving between cultures as they seek to enhance home-school relationships. Juxtaposed with the networked third-party awareness is that the families' views in this study call into question the efficacy of many standardized and taken-for-granted school-directed efforts such as newsletters and parent meetings that seek to create firm, linear bridges between homes and schools. Indeed, many of these unidirectional school-focused attempts to connect homes to schools, as the primary means of connection, were resisted by families and seen as invasive and ill-informed.

In the ways these families described their relationships with schools, the school and the home were to remain separate. They were seen to serve different functions in training children to navigate the new cultural context unfamiliar to the parents. This finding suggests that the dominant approach to home-school connection, in which the school directs efforts to connect with the home, may be at odds with parents' own pursuits for their children's education. In this study the nondominant families crossing cultures describe, and appear to be seeking, a different and more mutual type of relationship with the school wherein the school is seen less in terms of a defined place for teaching and learning and more as an entrée or doorway to a future life for their children. Thus, the school was viewed by these parents as a place with the potential to lead their children to desirable futures giving their children access to the skills and knowledge demanded by the mainstream world of jobs and success. 


\section{Conclusion}

These family conversations illuminate efforts to involve nondominant families crossing cultures in school through the third-party networks. As more families cross cultures, attention to understanding the families' networks offers schools the potential to inform new ways to approach home-school relationships with these families. This requires looking beyond the family's immediate microsystem to the third-party interactions within their networked ecological systems (Neal \& Neal, 2013). These connections need further exploration to identify those functions for which families are seeking input and support from the school and those they would prefer to manage independently, away from school.

The study has pointed to some promising ways forward in forging new relationships between schools and families. The promise of working within new kinds of relationships with families through a mutual exchange, rather than school-driven activity, is a positive goal highlighted in the recently released draft of Policy statement on family engagement: From the early years to the early grades (U.S. Department of Education, 2016). This statement calls for "systematically engaging families in their children's development, learning, and wellness, across early childhood and elementary education settings" (p.1). The present study suggests that such a goal requires engaging with the entire ecological system within which families are embedded. In other words, rather than primarily engaging the microsystem in home-school communication, schools should be encouraged to consider the potential of engaging the third-party networks when seeking to involve nondominant families crossing cultures.

Further, this study suggests that listening to nondominant families, mostly missing from the family engagement literature (Baquedano-López, Alexander, \& Hernandez, 2013), brings new insights into the perceptions of the role of home and school. These insights call for a thirdparty networked understanding of home-school communication and further inform school personnel in how to work together with these families in the best interests of their children with potential benefit for all children. 


\section{References}

Audet, G. (2008). La relation enseignant-parents d'un enfant d'une autre culture sous l'angledu rapport à l'altérité [The relationship to otherness in the relation of teacher-parents of a child from another culture]. Revue des Sciences de l'Éducation, 34(2), 333-350. doi:10.7202/019684ar

Barton, A. C., Drake, C., Perez, J. G., St. Louis, K., \& George, M. (2004). Ecologies of parental engagement in urban education. Educational Researcher, 33(4), 3-12.

Baquedano-López, P., Alexander, R. N., \& Hernandez, S. J. (2013). Equity issues in parental and community involvement in schools: What teacher educators need to know. Review of Research in Education, 37,149-182.

Biernacki, P., Waldorf, D. (1981). Snowball Sampling: Problems and Techniques of Chain Referral Sampling. Sociological Methods and Research, 10, 141-163.

Bronfenbrenner, Y. (1979). The ecology of human development. Cambridge, MA: Harvard University Press.

Bronfenbrenner, U. (1992). Ecological systems theory. In R. Vasta (Ed.), Annals of child development. Six theories of child development: Revised formulations and current issues (187-249). London, UK: Harris and Associates.

Carreira, M. \& Kagan, O. (2011). The Results of the National Heritage Language Survey:Implications for teaching, curriculum design, and professional development. Foreign Language Annals, 44(1), 40-63.

Carreon, G., Drake, C., \& Barton, A. (2005). The importance of presence: Immigrant parents' school engagement experiences. American Educational Research Journal, 42(2), 465498.

Charmaz, K. (2000). Grounded theory: Objectivist and constructivist methods, in N. K. Denzin, and Y. S. Lincoln (Eds.), Handbook of Qualitative Research. (2nd ed) (509-535). Thousand Oaks, CA: Sage.

Charmaz, K. (2014). Constructing Grounded Theory (2nd ed). Thousand Oaks, CA: Sage

Christenson, S. L., \& Sheridan, S. M. (2001). Schools and families: Creating essential connections for learning. New York, NY: The Guildford Press.

Chrispeels, J., \& Rivero, E. (2001). Engaging Latino families for student success: How parent education can reshape parents' sense of place in the education of their children. Peabody Journal of Education, 76(2), 119-169. 
Coll, C. T. \& Pachter, L. (2002). Ethnic and Minority Parenting. In M. H. Bornstein, (Ed.), Handbook of Parenting, Volume 4: Social Conditions and Applied Parenting, (2nd ed) (1-20). Mahwah, NJ: Lawrence Erlbaum Publishers.

Crozier, G., \& Davies, J. (2007). Hard to reach parents or hard to reach schools? A discussion of home-school relations, with particular reference to Bangladeshi and Pakistani parents. British Educational Research Journal, 33(3), 295-313.

de Carvalho, M. F. P. (2001). Rethinking family-school relations: A critique of parental involvement in schooling. Mahwah, NJ: Lawrence Erlbaum Associates, Publishers.

Hoover-Dempsey, K. V., Walker, J. M. T., Sandler, H. M., Whetsel, D., Green, C. L., Wilkins, A. S., \& Closson, K. (2005). Why do parents become involved? Research findings and implications. The Elementary School Journal, 106(2), 105-130.

Denessen, E., Bakker, J., \& Gierveld, M. (2007). Multi ethnic schools' parent involvement policies and practices. The School Community Journal, 17(2), 27-43.

Dedoose, Version 5.0.11, web application for managing, analyzing, and presenting qualitative and mixed method research data (2014). Los Angeles, CA: Socio-Cultural Research Consultants, LLC (www.dedoose.com).

Emerson, L., Fear. J., Fox, S., \& Sanders, E. (2012). Parental engagement in learning and schooling: Lessons from research. A report by the Australian Research Alliance for Children and Youth (ARACY) for the Family-School and Community Partnerships Bureau: Canberra.

Fleer, M. (2004). The cultural construction of family involvement in early childhood education: Some indigenous Australian perspectives. Australian Educational Researcher, 31(3), 5168.

Friese, Susanne (2011). Using ATLAS.ti for Analyzing the Financial Crisis Data [67 paragraphs]. Forum Qualitative Sozialforschung / Forum: Qualitative Social Research, 12(1), Art. 39. Retrieved from http://nbn-resolving.de/urn:nbn:de:0114-fqs1101397

Garcia Coll, C., Akiba, D., Palacios, N., Bailey, B., Silver, R., DiMartino, L., \& Chin, C. (2002). Parental involvement in children's education: Lessons from three immigrant groups. Parenting: Science and Practice, 2(3), 303-324.

Glaser, B. G. \& Strauss, A. L. (1967). The discovery of grounded theory: Strategies for qualitative research. Chicago, IL: Aldine Publishing Company.

Griffith, J. (2000). School climate as group evaluation and group consensus: Student and parent perceptions of the elementary school environment. Elementary School Journal, 101, 3561. 
Griffith, A. \& Smith, D. (2005). Mothering for schooling. New York, NY: Routledge.

Gutierrez, K. D., \& Rogoff, B. (2003). Cultural ways of learning: Individual traits or repertoires of practice. Educational Researcher, 32(5), 19-25.

Hilgendorf, A. (2012). Through a limiting lens: Comparing student, parent, and teacher perspectives of African American boys' support for school. School Community Journal, 22(2), 111-130.

Hughes, P., \& MacNaughton, G. (2000). Consensus, dissensus or community: The politics of parent involvement in early childhood education. Contemporary Issues in Early Childhood, 1(3), 241-262.

Hoover-Dempsey, K. V., \& Sandler, H. M. (1997). Why do parents become involved in their children's education? Review of Educational Research, 67(1), 3-42.

Iannaccone, A., \& Marsico, G. (2013). The family goes to school: Talks and rituals of an intercontextual meeting. In G. Marsico, K. Komatsu, and A. Iannaccone (Eds.), Crossing boundaries: Intercontextual dynamics between family and school (135-170). Charlotte, NC: Information Age Publishing.

Jensen, S. Q. (2011). Othering, identity formation and agency. Qualitative Studies, 2(2), 63-78.

Kanouté, F., \& Saintfort, M. (2003). La relation école-famille immigrante. [The immigrant family-school relationship]. Education Canada, 43(1), 28-31.

Kanouté, F., Vatz Laaroussi, M., Rachédi, L., \& Doffouchi, M. T. (2008). Familles et réussite scolaire d'élèves immigrants du secondaire. [Families and academic achievement of immigrant high school students]. Revue des Sciences de l'Éducation, 34(2), 265-289. doi:10.7202/019681ar

Kim, E. (2002). The relationship between parental involvement and children's educational achievement in the Korean immigrant family. Journal of Comparative Family Studies, $33(4), 529-540$.

Klein, A. (2008). From Mao to Memphis: Chinese immigrant fathers' involvement with their children's education. School Community Journal, 18(2), 91-118.

Lawrence-Lightfoot, S. (2003). The essential conversation: What parents and teachers can learn from each other. New York, NY: Random House.

Lea, T., Wegner, A., McRae-Williams, E., Chenall, R. \& Holmes, C. (2011). Problematising school space for Indigenous education: teachers' and parents' perspectives. Ethnography \& Education 6(3), 265-280. 
Li, G. (2006). What do parents think? Middle-Class Chinese immigrant parents' perspectives on literacy learning, homework, and school-home communication. School Community Journal, 16(2), 27-46.

Lim, M. (2012). Unpacking parent involvement: Korean-American parents' collective networking. School Community Journal, 22(1), 89-110.

Lopez, G. R., Scribner, J. D., \& Mahitivanichcha, K. (2001). Redefining parental involvement: Lessons from high-performing migrant-impacted schools. American Educational Research Journal, 38(2), 253-288.

Lyutykh, E. (2011). Russian language schools: Exploring heritage literacy beliefs and practices in families, instruction, and communities (Doctoral dissertation). ProQuest, UMI Dissertation Publishing ID 894454923.

Maxwell, J. A., 1992. Understanding and validity in qualitative research. Harvard Educational Review. 62(3), 279-300.

McCarthey, S. J. (2000). Home-school connections: A review of the literature. The Journal of Educational Research, 93(3), 145-153.

Mellor, S., \& Corrigan, M. (2004). The case for change: A review of contemporary research on Indigenous education outcomes. Australian Education Review. Melbourne: Australian Council for Education Research (ACER).

Mo, Y., \& Singh, K. (2008). Parents' relationships and involvement: Effects on students' school engagement and performance. RMLE Online: Research in Middle Level Education, 31(10), 1-11.

Moosa, S., Karabenick, S. A., \& Adams, L. (2001). Teacher perceptions of Arab parent involvement in elementary schools. School Community Journal, 11(2), 7-26.

Neal, J. W., \& Neal, Z. (2013). Nested or networked? Future directions for ecological systems theory. Social Development, 22(4), 722-737. doi:10.1111/sode

Neal, J. W., \& Neal, Z. (2014). The (In)compatibility of diversity and sense of community. American Journal of Community Psychology, 53, 1-12.

Nwosu, C., Batalova, J., \& Auclair, G. (2014). Frequently requested statistics on immigrants and immigration in the United States. Migration Policy Institute. Retrieved from www.migrationpolicy.org

Ochs, E., \& Taylor, C. (1992). Family narrative as political activity. Discourse \& Society, 3(3), 301-340. 
Okagaki, L., \& Sternberg, R. J. (1993). Parental beliefs and children's school performance. Child Development, 64(1), 36-56.

Pontecorvo, C. (2007). On the conditions for generative collaboration: Learning through collaborative research. Integrative Psychological and Behavioral Science, 41(2), 178186.

Pontecorvo, C., Fasulo, A., \& Sterponi, L. (2001). Mutual apprentices: The making of parenthood and childhood in family dinner conversations. Human Development, 44(6), 340-361.

Poza, L., Brooks, M. D., \& Valdés, G. (2014). Entre familia: Immigrant parents' strategies for involvement in children's schooling. School Community Journal, 24(1), 119-148.

Reschly, A. L. \& Christenson, S. L. (2014). Moving From“'Context matters' 'to engaged partnerships with families. Journal of Educational and Psychological Consultation, 22, $62-78$.

Settles, B. H. (2001). Being at home in a global society: A model for families' mobility and immigration decisions. Journal of Comparative Family Studies, 32(4), 627-645.

Said, E. (1995). Orientalism. London: Penguin Books [first published in 1978].

Sheldon, S. (2005). Parents' social networks and beliefs as predictors of parent involvement. The Elementary School Journal, 102(4), 301-316.

Siu, S. F. (2001). An ethnographic study of Chinese American family involvement in young children's education. In C. C. Park., A. L. Goodwin, \& S. J. Lee (Eds.), Research on the education of Asian and Pacific Americans (105-128). Greenwich, CT: Information Age.

Shumow, L., \& Lomax, R. (2002). Parental efficacy: Predictor of parenting behavior and adolescent outcomes. Parenting: Science and Practice, 2, 127-150.

Silva, L. C., Campbell, K., \& Wright, D. W. (2012). Intercultural relationships: Entry, adjustment, and cultural negotiations. Journal of Comparative Family Studies, 857-870.

Sohn, S., \& Wang, X. C. (2006). Immigrant parents' involvement in American schools: Perspectives from Korean mothers. Early Childhood Education Journal, 34(2), 125-132.

Strauss, A. L. \& Corbin, J. M. (1990). Basics of qualitative research. Grounded theory procedures and techniques. Newbury Park, CA: Sage.

Suarez-Orozco, C., \& Suarez-Orozco, M. (2001). Children of immigration. Cambridge, MA: Harvard University Press. 
Suarez-Orozco, C., Suarez-Orozco, M., \& Todorova, I. (2008). Learning a new land: Immigrant students in American society. Cambridge, MA: Harvard University Press.

Trumbull, E., \& Rothstein-Fisch, C. (2011). The intersection of culture and achievement motivation. School Community Journal, 21(2), 25-53.

Trumbull, E., Rothstein-Fisch, C., Greenfield, P. M., \& Quiroz, B. (2001). Bridging cultures between home and school: A guide for teachers. Mahwah, NJ: Lawrence Erlbaum Associates.

Trumbull, E., Rothstein-Fisch, C., \& Hernandez, E. (2003). Parent involvement in schooling: According to whose values? School Community Journal, 13(2), 45-72.

Tyler, K. M., Uqdah, A. L., Dillihunt, M. L., Beatty-Hazelbaker, R., Conner, T., Gadson, N., ... \& Stevens, R. (2008). Cultural discontinuity: Toward a quantitative investigation of a major hypothesis in education. Educational Researcher, 37(5), 280-297.

U.S. Department of Education. (2016). Policy statement on family engagement- From the early years to the early grades. Retrieved from http://www2.ed.gov/about/inits/ed/earlylearning/families.html

Vazquez-Nuttall , E., Li, C., \& Kaplan, J. P. (2006) Home-school partnerships with culturally diverse families. Journal of Applied School Psychology, 22(2), 81-10.

Valdez, G. (1996). Con respecto. Bridging the distances between families and school. New York, NY: Teachers College Press.

Walsh, D. (2002). The development of self in Japanese preschools: Negotiating space. In L. Bresler \& A. Ardichvili (Eds.), Research in international education: Experience, theory, and practice (213-245). New York, NY: Peter Lang.

Wang, D. (2008). Family-school relations as social capital: Chinese parents in the United States. School Community Journal, 18(2), 119-146.

Wong, S. W., \& Hughes, J. N. (2006). Ethnicity and language contributions to dimensions of parent involvement. School Psychology Review, 35(4), 645-662. 